\title{
EFFECT OF HEAD MANAGEMENT COMPETENCE ON TEACHER PERFORMANCE IN SMA NUSANTARA PLUS
}

\author{
Elysa Aryani ${ }^{1}$, Alifianti Uswatun $\mathbf{H}^{2}$, Hardian Dwi $\mathbf{P}^{3}$, Zahruddin ${ }^{4}$ \\ Islamic Educational Management Department, Universitas Islam Negeri Syarif Hidayatullah \\ Jakarta, Indonesia \\ Email: elysaaryani96@gmail.com¹, alifia.ana93@gmail.com², dwitra1305@gmail.com³, \\ zaharuddin@uinjkt.ac.id ${ }^{4}$ \\ DOI: http://doi.org/10.33650/al-tanzim.v5i2. 2177 \\ \begin{tabular}{l|l|l} 
Received: May 2021 & Accepted: July 2021 & Published: August 2021
\end{tabular}
}

\begin{abstract}
:
This study aims to determine the effect of principal managerial competence on teacher performance at senior high school Nusantara Plus. The method used in this study is quantitative. The samples in this study were all senior high school Nusantara Plus, totaling 35 people/respondents. The data collection instrument used was a questionnaire. Based on the research results on the determination test, the coefficient of determination ( $\mathrm{R}$ square) was 0.172 . The $\mathrm{R}$ square value of 0.172 comes from the square of the correlation coefficient or "R", which is $=0.172$ or equal to $17.2 \%$. This figure shows that the managerial competence variable $(X)$ affects the teacher performance variable $(\mathrm{Y})$ by $17.2 \%$, and $82.8 \%$ is influenced by other variables not examined.
\end{abstract}

Keywords: Managerial Competencies, Principals, Teacher Performance

\begin{abstract}
Abstrak:
Penelitian ini bertujuan untuk mengetahui tentang pengaruh kompetensi manajerial kepala skeolah terhadap kinerja guru di SMA Nusantara Plus. Penelitian ini menggunakan metode kuantitatif. Sampel pada penelitian ini adalah seluruh guru di SMA Nusantara Plus yang berjumlah 35 responden. Adapun instrument pengumpulan data yang digunakan adalah dalam bentuk angket. Berdasarkan hasil penelitian pada uji determinasi, ditemukan nilai koefisien determinasi ( $\mathrm{R}$ square) sebesar 0,172. Nilai $\mathrm{R}$ square 0,172 ini berasal dari pengkuadratan nilai koefisien korelasi atau " $R$ " yaitu $=0,172$ atau sama dengan 17,2 \%. Angka tersebut mengandung arti bahwa variabel kompetensi manajerial $(X)$ berpengaruh terhadap variabel kinerja guru $(\mathrm{Y})$ sebesar 17,2\%, dan 82,8\% dipengaruhi oleh variabel lainnya seperti tingkat pendidikan guru, supervisi pengajaran, program penataran, iklim yang kondusif, sarana dan prasarana, kondisi fisik dan mental guru.

Kata Kunci: Kompetensi Manajerial, Kepala Sekolah, Kinerja Guru
\end{abstract}




\section{INTRODUCTION}

Awareness of the importance of education can provide hope and better possibilities in the future have encouraged various efforts and attention from all levels of society towards every step and development of the world of education. Education is one of the efforts to improve the quality of human life; in essence, it aims to humanize humans, mature, and change behavior and improve quality for the better (Rifa'i, 2017; Amalia, 2020). In this case, the management of education requires management knowledge that can change the system better and with quality. Management science is used in education and various sectors, including economics, health, politics, and state administration (Hefniy \& Fairus, 2019; Rostiawati, 2020). The study of education management in Indonesia has also now been promoted for the noble goal of educating the nation's life. The success of educational administration is inseparable from one's ability to lead an educational institution or institution. Leadership becomes the world of business or industry (Dakir, 2019; Fauzi, 2020; Lubis, 2020).

The higher the social life of the community in line with the development of science and technology, the higher the demands of the needs of the community's social life. In the end, these demands lead to education because people believe that education can answer and anticipate these challenges (Maryanti et al., 2020). Education is one of the efforts that schools can make as institutions where people hope for a better life in the future. Education needs changes that can be made through changes and improvements in the management or management of instruction in schools.

The principal as an educational leader is the person most responsible for the success of education in his school (Fitria et al., 2017). The principal is concerned with leadership in the implementation of tasks and human relations. So the conditions that must be met are that someone who is elected or appointed as a school principal must have the ability to carry out his duties and foster good relations with all personnel. Regarding the principal's leadership in education, it includes the process of moving, influencing, motivating, and directing people in educational organizations/institutions, especially to achieve the goals that have been formulated. Thus it can be concluded that an educational leader, in this case, is the principal of the school, is required to have the ability to guide, mobilize and encourage and direct people in educational institutions, namely achieving academic goals that have been formulated previously (Arifin \& Permadi, 2007). School management led by the principal will be reflected in the results of school accreditation and evaluation of student learning outcomes. Several things that can affect the leadership of the principal, among others; 1) must know about management; 2) have the resilience to carry out their duties, and 3) have an organizational culture. Adversity is an individual's strength in overcoming obstacles, difficulties, and problems that are challenges in doing a job and are used as opportunities to achieve success (Seriyanti et al., 2020).

The description above means that the role of the principal is vital in determining the success or failure of a school in carrying out the principal's duties to educate the nation's life and develop a complete human being. The 
good or bad of a school is more determined by the professional ability of the principal as its management. The principal's function is not only as a manager but also as a thinker and developer (brainpower) whose main task is to think about the school's ability, so the principal is required to act as a professional leader. The hallmark of an experienced school principal is to master his work well beyond the average of other personnel in the school and have a high moral commitment to his career by his professional code of ethics.

Furthermore, Sanusi (2007) means that education management is an activity to manage various educational resources to realize the functions and roles of educational institutions in achieving national education goals. That means that each component of education will work to achieve goals based on their respective tasks to realize national education goals. There are seven school management, namely; curriculum management; management of learning or teaching programs; education personnel management; student management; financial management; facilities and infrastructure management; public relations management (Seriyanti et al., 2020).

Management is a process of using resources effectively to achieve specific goals or objectives. The term management is usually known in economics, which focuses on profit (profits) and commercial commodities. Teacher professionalism is the key to the smoothness and success of the learning process in schools (Dakir, 2018; Munawar, 2019). Because only professional teachers can create an active situation for students in learning activities (Danniarti, 2018). Professionalism develops with the progress of modern society. This requires a variety of specializations that are needed in an increasingly complex community. The problem of the educational profession is still widely discussed, both within education and outside education. Although many academic experts have put forward various views on this problem, one thing is for sure that the community feels the need for a teacher education institution that functions explicitly to prepare well-educated and well-trained teachers. The implication of this idea is the need to develop a suitable teacher education program and facilitate the formation of teachers who are professionally qualified and can be implemented efficiently in the socio-cultural conditions of society in Indonesia (Santoso et al., 2021)

Efforts to improve the quality of teachers have been carried out by the government in various ways, including by providing block grants to schools as stimulant funds to implement teacher professional development programs, forming subject teacher associations, establishing teacher scientific forum organizations, and publishing scientific journals for teachers. Teachers and also by empowering the Subject Teacher Consultation program (MGMP), which has been in existence in almost every district/city (Lisnawati, 2018). However, there are still many teachers in Indonesia who do not fully have professional teaching education. The profession is essentially a statement or an open promise that someone will devote himself to a position or job (Sormin, 2017)

Until now, the most concern in the world of education after the ratification of Law Number 14 of 2005 concerning Teachers and Lecturers in December 2005 is teacher certification. This is understandable because apart 
from being a new phenomenon, the term also affects the fate and the future. Various interpretations related to the understanding of teacher certification have emerged. Some understand that teachers who already have a bachelor's degree in education are automatically certified. Some understand that certification can only be obtained through special education conducted by the Education Personnel Education Institution (LPTK) appointed by the government. Several educational institutions use this vague understanding by opening various speculative programs with the label "certification," ranging from short-term (one month) to long-term (one year). Of course, the offer received a positive response from teachers, especially teachers who have not obtained a bachelor's degree in education or have not been certified (Laksmi, 2019).

Teacher performance is the ability of a teacher to perform actions by the goals that have been set, which includes aspects of planning teaching and learning programs, implementing the teaching and learning process, creating and maintaining optimal classes, controlling optimal learning conditions, and assessing learning outcomes (Selvi, 2010; Akyıldız \& Seçil, 2019). Performance is critical in determining a person's work quality, including a teacher (Purwanto et al., 2020). Every principal as an organizational leader needs to master and have the ability to motivate his subordinates so that elementary school principals can influence their subordinates; they must understand their subordinates' needs. The success of school management is primarily determined by the activities of empowering human resources (HR) because the principal as a leader in an organization should be aware and responsive to be able to maintain teacher performance and job satisfaction by encouraging teachers to carry out their duties by the rules and regulations (Merve \& Cagda, 2018; Yuliyati, 2020). Therefore, one of the principal's duties is to create professional teachers so that they can work by the directions given (Seriyanti et al., 2020)

From the description above, it can be concluded that to optimize school management, it is necessary to do professionalism and teacher performance to find out the weaknesses and strengths that exist to improve and improve school management. Based on this, the next researcher is interested in examining the principal's duties in terms of managerial competence owned by the principal, which is still not running optimally because there are still unfulfilled tasks in managerial competence related to teacher performance.

\section{RESEARCH METHODS}

This research uses a quantitative approach with data collection techniques through surveys. The survey was conducted to collect data sourced from information obtained from respondents as research samples. Survey research collects data to test hypotheses or answer questions about people's opinions on some topic or problem. A survey is an instrument for collecting data describing one or more specific characteristics.

The research sample is 35 senior high school Nusantara Plus teachers who have been teaching for more than two years. Data collection is done through several stages; 1) direct or observation, data collection by observing 
directly on the object under study; 2) Questionnaire, a method of collecting or distributing questions to respondents, hoping that they respond to these questions. After using research instruments, the work becomes more accessible, and the results are better, making it easier to process.

Table 1 : Likert Scale Model in Assessment of Questionnaire Items

\begin{tabular}{cccc}
\hline \multirow{2}{*}{ There is a } & \multirow{2}{*}{ Choice of your answer } & \multicolumn{2}{c}{ Score } \\
\cline { 3 - 4 } & Always & Positive & Negative \\
\hline 1 & Often & 3 & 1 \\
\hline 2 & Sometimes & 2 & 2 \\
\hline 3 & Never & 1 & 3 \\
\hline 4 & Source: Sugiyono (2016)
\end{tabular}

The data analysis technique used in this research is descriptive and inferential, which aims to test the research variables. 1) Descriptive analysis technique is a type of data analysis used to express or describe the characteristics of each research variable singly by analyzing the distribution of frequency, percentage, average (mean), and standard deviation. 2) Inferential Statistical Analysis To determine the normality of the data on the managerial competence of principals (variable X) and teacher performance (variable $Y$ ) that have been collected, a normality test of the data was carried out. 3) The test criteria are if the calculated $\mathrm{f}$ is greater than the $\mathrm{F}$ table at a significant level of $5 \%$, then $\mathrm{HO}$ is rejected, which states that the managerial competence of the principal has no significant effect on the social competence of teachers, and vice versa. On the other hand, if the T-count for high school is higher than the Ttable at a significant level of $5 \%$, then $\mathrm{H} 1$ is accepted, which states that the managerial competence of the principal has a significant effect on the social competence of teachers.

\section{RESULTS AND DISCUSSION}

The results of distributing questionnaires conducted electronically, researchers collected data for analysis to determine the managerial influence of principals on teacher performance at senior high school Nusantara Plus. Data processing is done with SPSS 16.0, and the results are as follows;

Table : 2 Normality Test Results StandardizedData

\begin{tabular}{llr}
\hline & & Residual No \\
\hline $\mathrm{N}$ & & 35 \\
\hline Normal Parameters ${ }^{\mathrm{a}, \mathrm{b}}$ & Mean & .0000000 \\
\cline { 2 - 3 } & Std. Deviation & 5.51464932 \\
\hline Most Extreme Difference & Absolute & 0.062 \\
\cline { 2 - 3 } & Positive & 0.039 \\
\cline { 2 - 3 } & Negative -, & 062 \\
\hline Statistical Test & & 0.062 \\
\hline Asymp. Signature. (2-tailed) & & $.2000^{\mathrm{c}, \mathrm{d}}$ \\
\hline
\end{tabular}


From the table above, the data normality test results using the Kolmogorov-Smirnov method can be seen that the significance is more significant than 0.05 , with a value of $0.200>0.05$, so that it can be said that the data are typically distributed.

Table 3 : Results ofHomogeneitytest

\begin{tabular}{cccc}
\hline Levene'sebagai statistic & DF1 & DF2 & Sig. \\
\hline 1.672 & 19 & 108 & 0.052 \\
\hline
\end{tabular}

Based on the homogeneity test results, it is known that the significance value is $0.52>0.05$, which means that the principal managerial variable and teacher performance are homogeneous or the same.

Table 4 : Results of the Termination Coefficient

\begin{tabular}{lllll}
\hline Model & $\mathrm{R}$ & $\mathrm{R}$ Square & Adjusted R Square & Std. Estimation Error \\
\hline 1 & $0.415^{\mathrm{a}}$ & 0.172 & 0.166 & 5.53550 \\
\hline a. Predictor: (Constant), Principal & \\
\hline
\end{tabular}

Based on the test results, the coefficient of determination is defined as the square of the correlation coefficient squared and multiplied by $100 \%$. So to review the results of the above analysis, the termination coefficient is ( $\mathrm{r} 2 \mathrm{xy} \mathrm{x}$ $100 \%)=0.415 \times 100 \%=0.172 \times 100 \%=17.2 \%$

Table 5 : Simple Regression Analysis

\begin{tabular}{|c|c|c|c|c|c|}
\hline \multirow[b]{3}{*}{ Model } & \multicolumn{3}{|c|}{ Coefficient } & & \multirow{4}{*}{$\begin{array}{l}\text { Sig. } \\
009 \\
\text { Princ } \\
\text { pal }\end{array}$} \\
\hline & $\begin{array}{l}\text { of Uns } \\
\text { Coeffic }\end{array}$ & $\begin{array}{l}\text { dardized } \\
\text { t of }\end{array}$ & $\begin{array}{l}\text { Standardized } \\
\text { Coefficients }\end{array}$ & \multirow{3}{*}{$\frac{t}{2,656}$} & \\
\hline & B & Std. Error & Beta & & \\
\hline 1 (Constant) & 14,935 & 5,624 & & & \\
\hline managerial & .486 & .093 & .415 & 5,235 & 000 \\
\hline
\end{tabular}

Based on table 5 above shows the count of 5.235 while $t$ table 1.97783 , then the value of $t$ count $>t$ table, which means $\mathrm{H}_{0}$ is rejected, the conclusion is that there is a significant influence on teacher performance. To prove the significance value, the author can prove from table 5 that the significance level for the principal's managerial value is obtained is 0.00 . This shows p-value $=$ $0.00<0.05$, which means $\mathrm{H}_{0}$ is rejected. Thus there is an influence between the principal's managerial and teacher performance.

The discussion of the results of this study is to provide an overview and research and understanding obtained from these results. Based on the research results and calculation of data obtained from the field, it is stated that there is an influence between the managerial competence of the principal on the teacher's performance at senior high school Nusantara Plus. A simple linear regression test was performed to determine whether the direction of the relationship between variable $X$ and variable $Y$ is positive or negative. The study results obtained a regression coefficient of 0.486 , which indicates the value of the regression coefficient is positive. Thus, it can be said that the 
direction of the influence of the principal's managerial competence $(X)$ has a positive effect on teacher performance $(\mathrm{Y})$. so that the regression equation is $\mathrm{Y}=$ $14,935+0,486 \mathrm{X}$.

Managerial principals have a positive and significant effect on teacher performance. Theoretically, the significant positive influence of leadership style on teacher performance strongly influences organizational progress, especially in educational institutions (Danim, 2017). One of the characteristics that a leader must have is motivating others to follow and realize the organization's vision. A quality leader must be able to change the behavior of his subordinates into someone who feels capable and highly motivated (Kartono, 2017; Von Dohlen \& Karvonen, 2018) so that organizational goals can be achieved together. Motivation is an important thing to give to employees because employees have the drive to achieve goals with motivation..

Leaders have great control over teacher performance. Teacher performance indicators, namely; Mastering the material to be taught, managing teaching and learning programs, managing classes (Muazza et al., 2018), using learning resource media, mastering educational foundations, managing teaching and learning interactions, assessing student learning achievement (Syafi'i, 2018), recognize the functions and programs of guidance and counseling, recognize and carry out administration, understand the principles of managing research results, thinkers, planners. The implementation of the learning process is in the teacher's hands, so the teacher must be self-aware, goal-conscious, and environmentally aware because awareness is the primary capital as a developer of performance culture (Susilowat, 2019).

To support the success of teacher performance as above, various supporting factors are needed, including teacher performance motivation. The urge to do good for the teacher should come from within oneself. Still, motivational efforts from outside can also provide the teacher's work spirit, for example, the encouragement given by the principal (Suprihatiningrum, 2014) Teachers have a more excellent work ethic to succeed in carrying out the learning process compared to teachers who are not supported by a work ethic in implementing teachers who have a different ethos (Muhaimin, 2017). A work environment that can support teachers to carry out their duties effectively and efficiently, including a socio-psychological climate, namely; a harmonious atmosphere and harmonization between teachers, teachers, and principals and teachers, principals, and staff, can support the success of teacher performance.

\section{CONCLUSION}

Based on the results of research that has been done, it can be concluded that there is an influence between variable $X$ (Managerial Competence of Principals) and variable $Y$ (Teacher Performance) is positive although in the low category. The managerial role of the principal is very instrumental in improving the performance of senior high school Nusantara Plus teachers. In addition to organizational factors, other aspects can improve teacher performance, including; teacher's work motivation, work environment, work climate, and existing corporate culture. Teacher performance is indicated by teacher behavior in carrying out educational and teaching tasks based on 
predetermined teacher competency indicators, namely, personality competence, professional competence, academic competence, and social competence. The main things that are very important and must be fulfilled by the principal in improving the performance of their teachers are; The urge to do the job well and responsibly should come from within the teacher, but motivational efforts from outside can also give the teacher the spirit of work, for example, the encouragement given by the principal to the teacher.

\section{REFERENCES}

Akyıldız, T., \& Seçil. (2019). Do 21st Century Teachers Know about Heutagogy or Do They Still Adhere to Traditional Pedagogy and Andragogy? International Journal of Progressive Education, 15(6), 151-169. https://doi.org/10.29329/ijpe.2019.215.10

Amalia, V. (2020). Strategi Komunikasi Humas dalam Meningkatkan Public Trust di Perguruan Tinggi (Studi Kasus di Universitas Nurul Jadid, Paiton, Probolinggo). Al-Tanzim: Jurnal Manajemen Pendidikan Islam, 4(1), 13-23. https://doi.org/10.33650/al-tanzim.v4i1.812

Arifin, \& Permadi. (2007). Kepemimpinan Transformasional Kepala Sekolah dan Komite. Bandung: Saran Panca Karya Nusa.

Dakir. (2018). Pengaruh Gaya Kepemimpinan Situasional Kepala Sekolah dalam Supervisi Akademik terhadap Kompetensi Profesional dan Kinerja Guru. Yogyakarta: K-Media.

Dakir. (2019). Manajemen Pemasaran Lembaga Pendidikan Islam. Yogyakarta: KMedia.

Danim. (2017). Kepemimpinan Pendidikan. Bandung: Alfabeta.

Danniarti. (2018). Modul Panduan Profesionalisme Guru yang Efektif dalam Proses Pembelajaran. Palembang: CV Amanah.

Fauzi, A. (2020). Manajemen Mutu Pendidikan Islam Terpadu; Strategi Pengelolaan Mutu Madrasah dan Sekolah di Era Revolusi Industri 4.0. Yogyakarta: Pustaka Pelajar.

Fitria, H., Mukhtar, M., \& Akbar, M. (2017). The Effect of Organizational Structure and Leadership Style on Teacher Performance in Private Secondary School. IJHCM (International Journal of Human Capital Management), 1(02), 101-102.

Hefniy, \& Fairus, R. N. (2019). Manajemen Strategi dalam Meningkatkan Mutu Pelayanan Kepegawaian. Al- Tanzim: Jurnal Manajemen Pendidikan Islam, 3(1), 169-197.

Kartono. (2017). Pemimpin dan Kepemimpinan. Jakarta: PT Rajawali Grafindo Persada.

Laksmi, N. L. P. S., Agung, A. A. G., \& Sudirman, S. (2019). Hubungan Kepemimpinan Pelayan, Kompetensi Manajerial Kepala Sekolah, Budaya Organisasi, dan Motivasi Kerja dengan Kinerja Guru di Gugus PAUD Tunjung Kecamatan Denpasar Utara. Jurnal Administrasi Pendidikan Indonesia, 10(2), 148-156. 
Lisnawati, R. (2018). Fungsi Manajemen Kepala Sekolah, Motivasi, dan Kinerja Guru. Jurnal Pendidikan (Teori dan Praktik), 2(2), 143-149. https://doi.org/10.26740/jp.v2n2.p143-149

Lubis, A. F. (2020). Manajemen Kurikulum Berbasis Kerangka Kualifikasi Nasional Indonesia (KKNI) di Perguruan Tinggi Islam. Al-Tanzim: Jurnal Manajemen Pendidikan Islam, 4(2), 28-40. https://doi.org/10.33650/altanzim.v4i2.1248

Maryanti, N., Rohana, R., \& Kristiawan, M. (2020). The Principal's Strategy in Preparing Students Ready to Face The Industrial Revolution 4.0. Journal of Educational Review, 2(1), 54-69., 2 (1), 54-69.

Merve, U., \& Cagda, K. C. (2018). Teachers Opinions of Human Resources Management Functions in Private Schools. Educational Research and Reviews, 13(12), 487-494. https:// doi.org/10.5897/err2017.3407

Muazza, M., Hadiyanto, H., Heny, D., Mukminin, A., Habibi, A., \& Sofwan, M. (2018). Analisis Kebijakan Pendidikan Inklusi: Studi Kasus di Sekolah Dasar Jambi. Jurnal Kependidikan: Penelitian Inovasi Pembelajaran, 2(2), 112.

Muhaimin. (2017). Manajemen Pendidikan Aplikasinya dalam Penyusunan Rencana Pengembangan Sekolah/Madrasah. Jakarta: Kencana.

Munawar, M. (2019). Supervisi Akademik: Mengurai Problematika Profesionalisme Guru di Sekolah. Al-Tanzim: Jurnal Manajemen Pendidikan Islam, 3(1), 135-155. https:// doi.org/10.33650/al-tanzim.v3i1.522

Purwanto, A., Sopa, A., Primahendra, R., Kusumaningsih, S. W., \& Pramono, R. (2020). Pengaruh Gaya Kepemimpinan Transaksional, Transformational, Authentic dan Authoritarian terhadap Kinerja Guru Madrasah Tsanawiyah di Kudus. Al-Tanzim: Jurnal Manajemen Pendidikan Islam, 4(1), 70-80. https://doi.org/10.33650/al-tanzim.v4i1.938

Rifa'i, M. (2017). Kebijakan Pendidikan Islam dalam Era Otonomi Daerah. AlTanzim : Jurnal Manajemen Pendidikan Islam, 1(1), 99-114.

Rostiawati, E. (2020). Efektifitas Manajemen Kepemimpinan dalam Menciptakan Good Governance. Al-Tanzim: Jurnal Manajemen Pendidikan Islam, 4(1), 59-69.

Santoso, T., Giyoto, G., Baidi, B., \& Kusmanto, H. (2021). Challenges of Al Islam and Kemuhammadiyahan (AIK) Learning with Baitul Arqam Model. AlTanzim: Jurnal Manajemen Pendidikan Islam, 5(1), 69-82. https://doi.org/10.33650/al-tanzim.v5i1.1644

Selvi, K. (2010). Teachers' Competencies. Cultura: International Journal of Philosophy of Culture and Axiology, 7(1), 167-175. https://doi.org/10.5840/cultura20107133

Seriyanti, N., Ahmad, S., \& Destiniar, D. (2020). Pengaruh Kepemimpinan Kepala Sekolah dan Peran Komite Sekolah terhadap Keberhasilan Manajemen Berbasis Sekolah. JMKSP (Jurnal Manajemen, Kepemimpinan, dan Supervisi Pendidikan), 6(1). https://doi.org/10.31851/jmksp.v6i1.3922

Sormin, D. (2017). Manajemen Kepala Sekolah dalam Meningkatkan Mutu Pendidikan di SMP Muhammadiyah 29 Padangsidimpuan. Al-Muaddib: Jurnal Ilmu-Ilmu Sosial \& Keislaman, 2(1), 129-146. 
Suprihatiningrum, J. (2014). Guru Profesional. Pedoman Kinerja, Kualifikasi, $\mathcal{E}$ Kompetensi Guru. Yogyakarta: Ar-Ruzz Media.

Susilowat. (2019). Transinternalisasi Nilai-nilai Kepesantrenan melalui Konstruksi Budaya Religius di Sekolah. Jurnal Pendidikan Agama Islam, 16(1), 1-12.

Syafi'i, A., Marfiyanto, T., \& Rodiyah, S. K. (2018). Studi tentang Prestasi Belajar Siswa dalam berbagai Aspek dan Faktor yang Mempengaruhi. Jurnal Komunikasi Pendidikan, 2(2), 115-123.

Von Dohlen, H., \& Karvonen, M. (2018). Teachers' Self-Reported Leadership Behaviors in Formal and Informal Situations. International Journal of Teacher Leadership, 9(2), 69-89.

Yuliyati, E. (2020). Pengembangan Sumber Daya Manusia berbasis Total Quality Management di SMK Muhammadiyah Prambanan. Al-Tanzim: Jurnal Manajemen Pendidikan Islam, 4(1), 24-35. https://doi.org/10.33650/al-tanzim.v4i1.967 